Bangladesh J. Zool. 45(2): 185-188, 2017

\title{
FIRST RECORD OF GREATER FLAMINGO PHOENICOPTERUS ROSEUS FROM SOUTH EAST COASTAL BANGLADESH
}

\author{
Asif Ahmed* and Humayra Mahmud \\ Department of Zoology, University of Dhaka, Dhaka-1000, Bangladesh,
}

Flamingos are a type of wading birds under the family Phoenicopteridae. There are six species of flamingos found in this world. Among them, the Greater Flamingo Phoenicopterus roseus can be readily identified. Greater Flamingo has the most diversified habitat in the wild. It is considered as 'Least Concern' according to IUCN Redlist (2016).

This species is regularly seen from West Africa eastward throughout the Mediterranean to South West and South Asia, and throughout Sub-Saharan Africa. The Palearctic population is estimated to number between 205,000 and 320,000, the South West and South Asian populations combined at 240,000, and the Sub-Saharan African populations between 100,000 and 120,000 (Delany and Scott 2006). The Palearctic population appears to be increasing, while the Asian and Sub-Saharan African populations appear to be stable (Delany and Scott 2006). Though this species is very common in India, especially in Gujarat, Rajasthan and Odisha, it had never been seen in Bangladesh. In 1967, Prof. Harun-er Rashid speculated that Greater Flamingo could occur in East Pakistan, and following his lead Ali and Ripley (1964-78), included Bangladesh in its range. However, as there was no reliable record of this species in Bangladesh, it was treated as a hypothetical and unconfirmed species (Siddiqui et al. 2008). The speculations finally came true in December 2016, although in an unfortunate circumstance.

A hunting party found a flock of five large birds feeding in the braided Jamuna River towards the end of December. Despite being illegal, hunters still shoot down migratory ducks for their "pleasure". The hunting party had never seen such bizarre birds so they shot at the flock and killed one bird. They collected the dead bird and took their photos with it. One of them held the dead bird's bill up above his head while its feet touched the ground.

The birds were totally unknown to the hunters, and one of them was curious to identify the bird, so he sent the photograph to a birder who could identify it. That birder became excited recognizing it as a flamingo. He repeatedly asked the

*Author for corresponding: <ahmedasifbd@live.com>.

(c) 2017 Zoological Society of Bangladesh DOI: http://dx.doi.org/10.3329/bjz.v45i2.35713 
hunter who finally gave some of the details of the circumstances of the photo, and through him the photo was shared and the birding community came to know about the first specific occurrence of the Greater Flamingo in Bangladesh. What should have been a celebration for birders was, however, a matter of sorrow since one bird was killed and other scared away by the hunters.

Within two months of that tragic incident, an immature Greater Flamingo was found at Kohelia Channel in Matarbari $\left(21^{\circ} 27^{\prime} 40^{\prime \prime} \mathrm{N} 91^{\circ} 59^{\prime} 57^{\prime \prime} \mathrm{E}\right)$, Moheshkhali, Chittagong, once a noteworthy bird-habitat. In the afternoon of 06 February 2017, the author and his other five team mates observed the bird for a few minutes and some photographs were taken. The bird was busy feeding on the muddy bank of the channel. It is unknown whether this was a survivor of the flock seen in Jamuna or not. It was readily identified as a flamingo based on its long thin neck, long legs and kinked bill and as an immature Greater Flamingo by its greyish-white head, neck and body, brown-streaked coverts, grey based black bill and grey legs. These constitute the first and second confirmed records of this species for Bangladesh, and include the first live photographic record. It is presumed that these were vagrants from India.

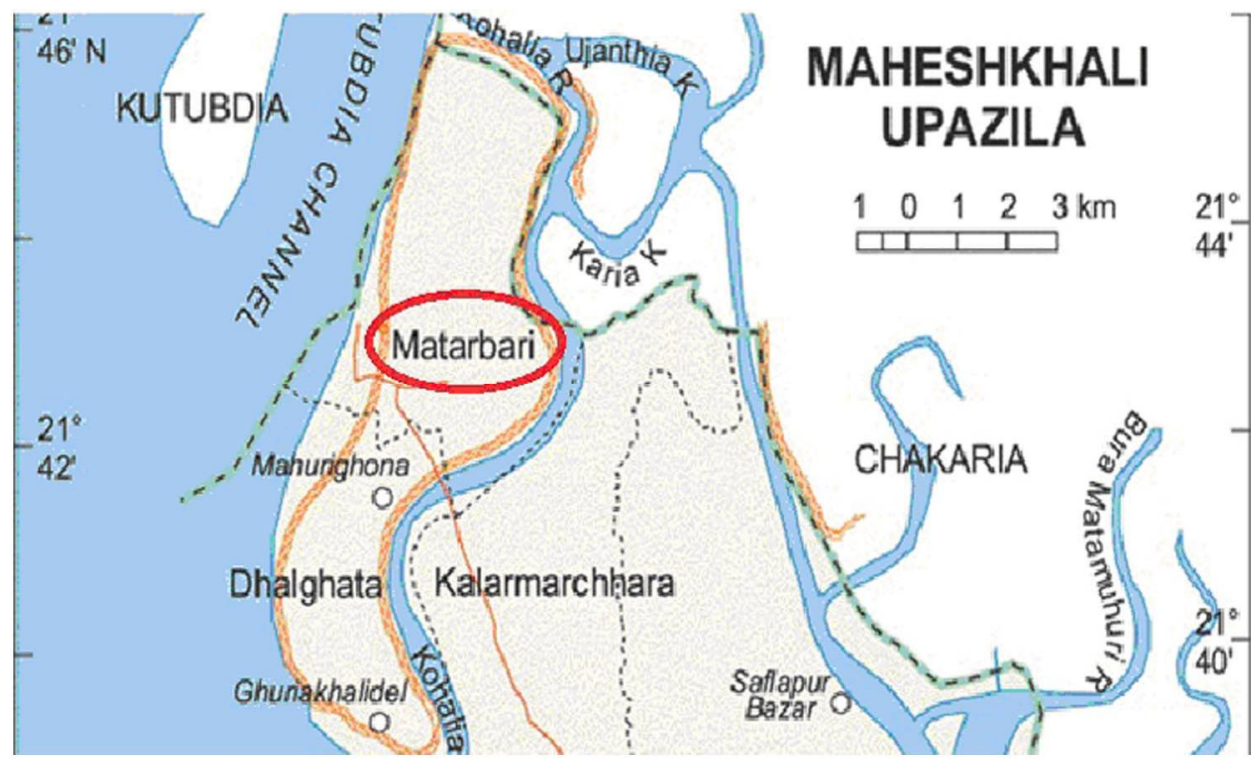

Fig. 1. Map depicting location where Phoenicopterus roseus was spotted.

Moheshkhali Island covers an area of approximately two hundred and sixtyeight square kilometers, and is blanketed in breathtaking mangrove jungles, spectacular ranges of hills and striking landscapes, with some hills standing at 
just over three hundred meters. Kohelia Channel of Matarbari is one of the very important ground for many wildlife species. Previous surveys of the Moheshkhali Channel found 79 species of fish, including 78 bony fish species. The site is very rich in mollusks and crustaceans. Crustaceans include various species of portunid crab, Mud Crab and Blue Swimmer Crab. Of particular importance is

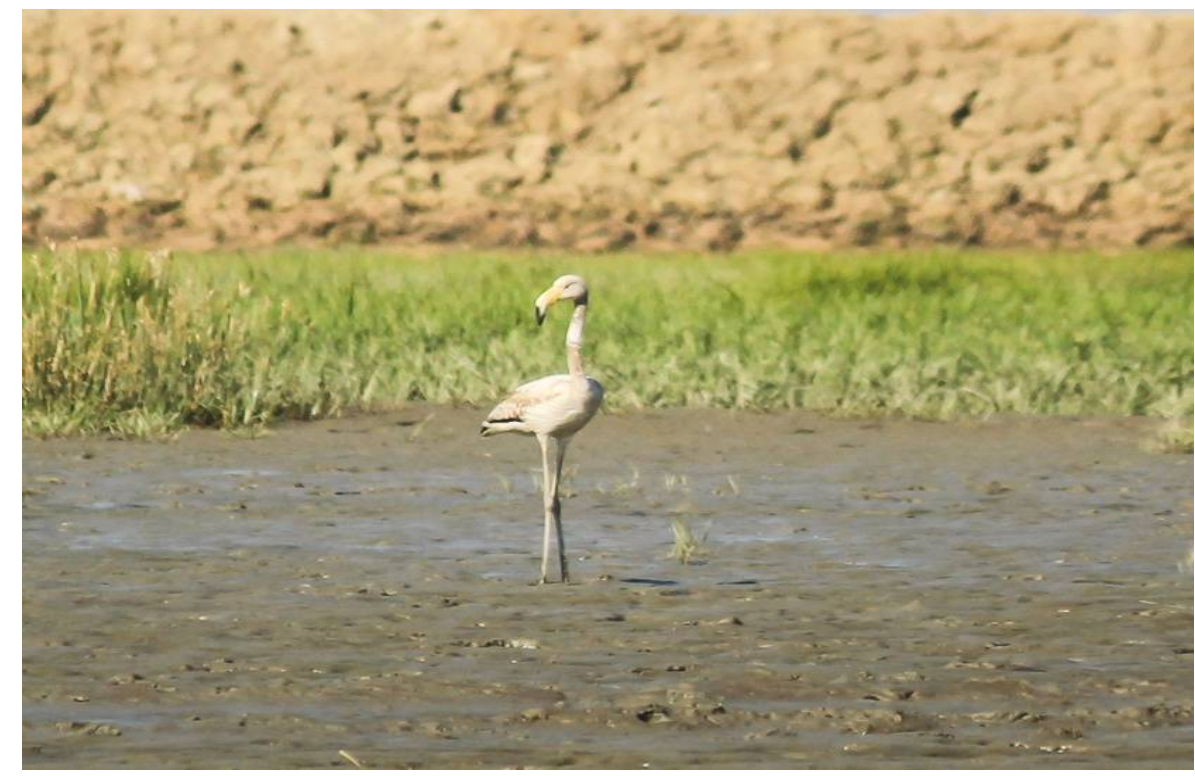

Fig. 2. Phoenicopterus roseus in its natural habitat at Kohelia Channel, Matarbari, Moheskhali, Chittagong

the Indian Horseshoe Crab, which is considered a living fossil and is listed as a threatened species. A total of 19 species of peneaid, solenocerid, sergestid and careidean prawn species have been recorded in a number of surveys of the Moheshkhali channel. The mangrove and mudflat of Moheshkhali are nesting, roosting, resting and wintering ground for more than 70 species of migratory water fowls and shorebirds including four globally threatened bird species (Chowdhury et al. 2011).

Acknowledgements: The authors thank Matarbari Power Plant Project for supporting their fieldwork. Special thanks to Mr. Omar Shahadat, Mr. Md. Mokhlesur Rahman and Mr. Md. Mahbub Alam for their help in identification.

\section{LITERATURE CITED}

ALI, S. and RIPLEY, S.D. 1964-1978. Handbook of the birds of India and Pakistan. Vol. 1-10. Oxford University Press and BNHS, Bombay. 
CHOWDHURY, S. U., FOYSAL, M., DAS, D. K., MOHSANIN, S., DIYAN, M. A. A. and ALAM, A. B. M. S. 2011. Seasonal occurrence and site use by shorebirds at Sonadia Island, Cox's Bazar, Bangladesh. Wader Study Group Bull. 118(2): 77-81.

DELANY, S. and SCOTT, D. S. 2006. Waterbird population estimates. Wetlands International, Wageningen, The Netherlands.

IUCN Red List of Threatened Species 2017: e.T22697360A119273745.

http://dx.doi.org/ 10.2305/IUCN.UK.2017-3.RLTS.T22697360A1 19273745.en. Downloaded on 19 February 2018.

RASHID, H. 1967. Systematic list of the birds of East Pakistan. Asiatic Society of Pakistan, Dacca. $144 \mathrm{pp}$.

SIDDIQUI, K.U., ISLAM, M.A., KABIR, S.M.H., AHMAD, M., AHMED, A.T.A., RHAMAN, A.K.A., HAQUE, E.U., AHMED, Z.U., BEGUM, Z.N.T., HASSAN, M.A., KHONDKER, M. and RAHMAN, M.M. (eds.). 2008. Encyclopedia of flora and fauna of Bangladesh, Vol. 26. Birds. Asiatic Society of Bangladesh, Dhaka. 622 pp. 